\title{
Safe water access, motivation and community participation at arsenic affected rural area of Jessore, Bangladesh: insights and realism
}

\author{
Md. Abu Shamim Khan ${ }^{1}$, Md. Waliullah1, Maruf Hossain'1, Bablu Hira Mandal' ${ }^{2}$, Umme \\ Habiba $^{2}$ and M. N. A. Siddique ${ }^{3}$
}

${ }^{1}$ Environmental Laboratory, Arsenic Center, Asia Arsenic Network, Jessore-7400

${ }^{2}$ Dept. of Chemical Engineering, Jessore University of Science and Technology (JUST), Jessore-7400

${ }^{3}$ Soil Resource Development Institute, Ministry of Agriculture, Bangladesh

Article info. ABSTRACT

\section{Key Words:}

Arsenic, Arsenocosis, Safe water, Community, Awareness

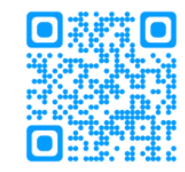

Received: 16.07.2016

Published: 14.11 .2016

For Any Information: ask.author@journalbinet.com
A trace level of arsenic in drinking water is toxic for human body. Ground water arsenic contamination is well known in the world. Arsenic in ground water is a serious health threat in arsenic contaminated areas. Last 20 years, many arsenic mitigation projects have been implemented at arsenic prone areas of Bangladesh. This study investigated the present status of existing integrated arsenic mitigation projects activities. Study was conducted on three village of Jessore district in Bangladesh where more than seven thousand people have been facing arsenic contamination problems in ground water. A total of 600 samples were collected following household survey method. Analysis suggested that slightly over half of the respondents are educated and nearly $42 \%$ was engaged withagriculture.41\% and $37 \%$ people were known about arsenic and arsenicosis. Arsenic safe, arsenic contaminated and not tested tube wells were $51 \%, 23 \%$ and $26 \%$ respectively. It was found that $52 \%$ and $46 \%$ people were using arsenic safe water from deep tubewell and shallow tubewell which was installed by GOs and NGOs. But it was found that 2\% people were still using arsenic contaminated tubewell water. This study found that 70\% and 35\% people were interested to pay their user share for safe water device installation and its maintenance purpose. People of arsenic prone areas were changing their habit to use arsenic safe water from deep tubewell for saving their lives from arsenicosis diseases. Arsenic mitigation programme motivated arsenic affected people increased their knowledge; hence changed drinking water use practice. Furthermore, this study found that community participation was not enough for safe water system maintenance. But vulnerable areas 
of arsenic affected people solved their arsenic problem by using arsenic safe water sources and its maintenance by user participation. Arsenic mitigation project activities were given a great benefit for awareness building and sustainable safe water supply.

Citation: Khan, M. A. S., Waliullah, M., Hossain, M., Mandal, B. H., Habiba, U. \& Siddique, M. N. A. (2016). Safe water access, motivation and community participation at arsenic affected rural areas of Jessore, Bangladesh: insights and realism. Journal of Science, Technology and Environment Informatics, 04(01), 260-269.

(C) 2016, Khan et al. This is an open access article distributed under terms of the Creative Common Attribution 4.0 International License.

\section{Introduction}

Water is a basic requirement of human life. Right to source of safe drinking water is universal human right. The government of Bangladesh is committed to provide safe water for all (FAO, UNICEF, WHO \& WSP Report, 2010). Safe water means pathogens and metal contaminants free water. Arsenic pollution has been reported from more than70 countries on six continents (Bhattacharya et al., 2002). Contamination of arsenic in ground water poses a risk to the health of millions of people; especially in densely populated river deltas of the south-east Asia (Bangladesh, China, Taiwan, Cambodia, Laos, India, Nepal, Myanmar, Pakistan and Vietnam). However, the scale of the problem is much larger in Bangladesh than in any other country of the world (TOROKU report, 2005). Arsenic poisoning in ground water is well known both nationally and internationally. The world health organization (WHO) has described the situation of arsenic contamination in Bangladesh as the largest poisoning of a population in the history (Smith et al., 2000). People are changing their habits to use ground water instead of surface water for reduction of water borne diseases (Diarrhea, Dysentery, Typhoid \& Cholera) (Hossain et al., 2001). Bangladesh is heavily dependent on ground water for drinking, cooking and irrigation purposes. So it is evident that arsenic contamination in ground water is a major problem in rural Bangladesh. A major part of village people are suffering from arsenicosis due to consuming arsenic contaminated water. About 80 million people in 61 districts out of 64 districts pose a serious health threat due to using arsenic contaminated ground water (British Geological Survey Report, 1999). Recent studies have indicated that arsenic constitutes a serious health risk via arsenic contaminated water and food (Saha, 1999). Arsenic is a accumulative substance, which is slowly passes out of the body through the urine, hair, finger or toe nails and skin. It may take around 10 years after consuming arsenic contaminated water for appearing the symptoms of arsenicosis (Saha, 1999). The arsenicosis symptoms period depends on the concentration of arsenic ingested; the length of exposure and immunity level of the person and body weight. Arsenicosis symptoms are skin pigmentation, eye infections, trachea and cancer (Caroli et. al. 1996). Arsenic contaminated water is not safe for drinking and cooking. According to DGHS data 38412 arsenicosis patients were suspected due to using arsenic contaminated water for drinking and cooking (SOS survey report, 2006). Arsenic safe water is the first priority for arsenicosis patients. In arsenic contaminated areas surface water is not available and ground water is not safe for drinking and cooking. In arsenic prone areas, safe water supply is a challenge, due to absence of sustainable water treatment technology, critical geological condition, water quality and climate change issues (APSU Report, 2006). Safe water is mandatory, where surface water is unavailable and ground water is contaminated by arsenic and in some areas salinity too. In case of arsenic contamination in drinking water, government and none-government organization (NGO) taken several initiatives through various arsenic mitigation projects with financial assistance from national and international development partners (Hossain et al., 2001). Governments and nongovernments organizations were working on arsenic mitigation and water supply projects in Bangladesh whose activities included motivation through awareness, water quality monitoring, arsenicosis patients' management, community development and safe water supply innovations (APSU Report, 2006). Intensity of arsenic contamination in ground water is much higher in the southwestern and south-eastern parts of Bangladesh. Jessore district is located at the north part of southwest Bangladesh. In Jessore district average arsenic contamination was $53 \%$ and the highest level of arsenic contamination was observed at Jhikargachha sadar union under Jhikargachha upazilla (NAMIC 
Data, 2004; JICA and AAN Report, 2015a). A total number of 1537 arsenicosis patients were suspected in Jessore district and while 375 arsenicosis patients were suspected at Jhikargachha upazila (SOS Survey report, 2006; JICA and AAN Report, 2015a). Jhikargachha upazila is the most vulnerable arsenic contaminated zone in Jessore district and Jhikargachaa sadar union was given priority to implement arsenic mitigation project (NAMIC Data, 2004).Various organizations conducted awareness campaigns at rural areas and also tried to mitigate the situation by giving alternative water supply options and arsenic removal technologies. More than23 safe devices were installed at Padmapukur, Srirampur and Sagarpur villages at Jhikargachha union; which supply arsenic safe water in these areas (JICA and AAN Report, 2015a; JICA and AAN Report, 2015b). During implementation of those projects, safe water supply systems have been encountered many difficulties due to lack of knowledge on water safety and inadequate community participation (JICA and AAN Report, 2015a). Arsenic mitigation project sustainability depends on knowledge development on water safety and regular maintenance of safe water system through community participation (JICA and AAN Report, $2015 b)$. Good practices of water safety and maintenance through community participation can save our lives from arsenic contamination. Thus this study aims to evaluate outcome of arsenic mitigation projects and or activities such as knowledge development on water safety and health, to evaluate practice of using arsenic safe water and maintenance cost sharing through user participation.

\section{Materials and Methods}

Study and survey method: Study area included one upazila of Jessore district, which is the south western part of Bangladesh; Jhikargachha upazila is one of the upazila which is affected by arsenic contamination problem considerably. Jhikargachha upazila has 11 unions and one pouroshova. Jhikargachha sadar union has 19 villages, 6107 families, population was 27623 and shallow tubewells were 4373 (NAMIC Data, 2004; JICA and AAN Report, 2015a; JICA and AAN Report, 2015b). At Jhikargachha union average 33\% shallow tubewells were arsenic contaminated (JICA and AAN Report, 2015a). General information about study area is shown in table 01 while a list of arsenic project and or program has been shown in table 02. Survey was conducted at Sagarpur, Padmapukur and Sreerampur villages at Jhikargachha sadar union. Sagarpur, Padmapukur and Sreerampur village arsenic contamination status, no. of arsenicosis patients and no. of safe water devices were shown in Figure 01 and Table 01. Survey was conducted in March, 2016formonitoring the present status of previously conducted arsenic mitigation projects activities like operational status, drinking water using pattern, user's participation, arsenic related knowledge development and behavioural changing etc. Survey was conducted by using household based survey method. Surveyor visited house to house and interviewed with house hold owner for collecting information about arsenic mitigation and water supply related predefined questionnaire. Study was conducted at three villages as random sampling method. For collecting information, survey area was divided into three parts based on the arsenic contamination intensity. During sample collection 600 samples were distributed into three villages according to family members of each village.

Table 01. General information about the study area

\begin{tabular}{|c|c|c|c|c|c|c|}
\hline \multirow{2}{*}{$\begin{array}{l}\text { Village } \\
\text { Name }\end{array}$} & \multirow{2}{*}{$\begin{array}{l}\text { No. of } \\
\text { families }\end{array}$} & \multicolumn{3}{|c|}{ Population } & \multirow{2}{*}{$\begin{array}{l}\text { Arsenic } \\
\text { contamination } \\
(\%)\end{array}$} & \multirow{2}{*}{$\begin{array}{l}\text { No. of } \\
\text { safe water } \\
\text { devices }\end{array}$} \\
\hline & & Male & Female & Total & & \\
\hline Sagarpur & 263 & 553 & 550 & 1103 & 99 & 6 \\
\hline Sreerampur & 1157 & 2394 & 2480 & 4874 & 19 & 12 \\
\hline Padmapukur & 407 & 787 & 780 & 1667 & 67 & 5 \\
\hline Total & 1827 & 3734 & 3810 & 7644 & 62 & 23 \\
\hline
\end{tabular}


J. Sci. Technol. Environ. Inform. 04(01): 260-269 | Khan et al. (2016)

EISSN: 2409-7632, www.journalbinet.com

DOI: $10.18801 /$ jstei.040116.29

Table 02. Project and or program names on arsenic mitigation and implementing organization

\begin{tabular}{|c|c|c|c|}
\hline Name of projects & Working area & $\begin{array}{l}\text { Implementation } \\
\text { periods }\end{array}$ & Organization \\
\hline BAMWSP Project & \multirow{7}{*}{$\begin{array}{l}\text { Jhikargachha Upazila } \\
\text { Jessore District }\end{array}$} & $2000-2002$ & DPHE-UNICEF \\
\hline Arsenic Mitigation Project & & $2003-2007$ & DRO(NGO) \\
\hline BRAC WASH Project & & $2005-2015$ & BRAC WASH \\
\hline MHSGWAPB Project & & 2006-2007 & NGO Forum \\
\hline BETV-SAM Project & & $2007-2008$ & OCETA-BCSIR-NGO Forum \\
\hline MBSWSS Project & & $2013-2015$ & JICA-AAN \\
\hline BRWSST Project & & 2014-2015 & DPHE-NGO Forum \\
\hline
\end{tabular}
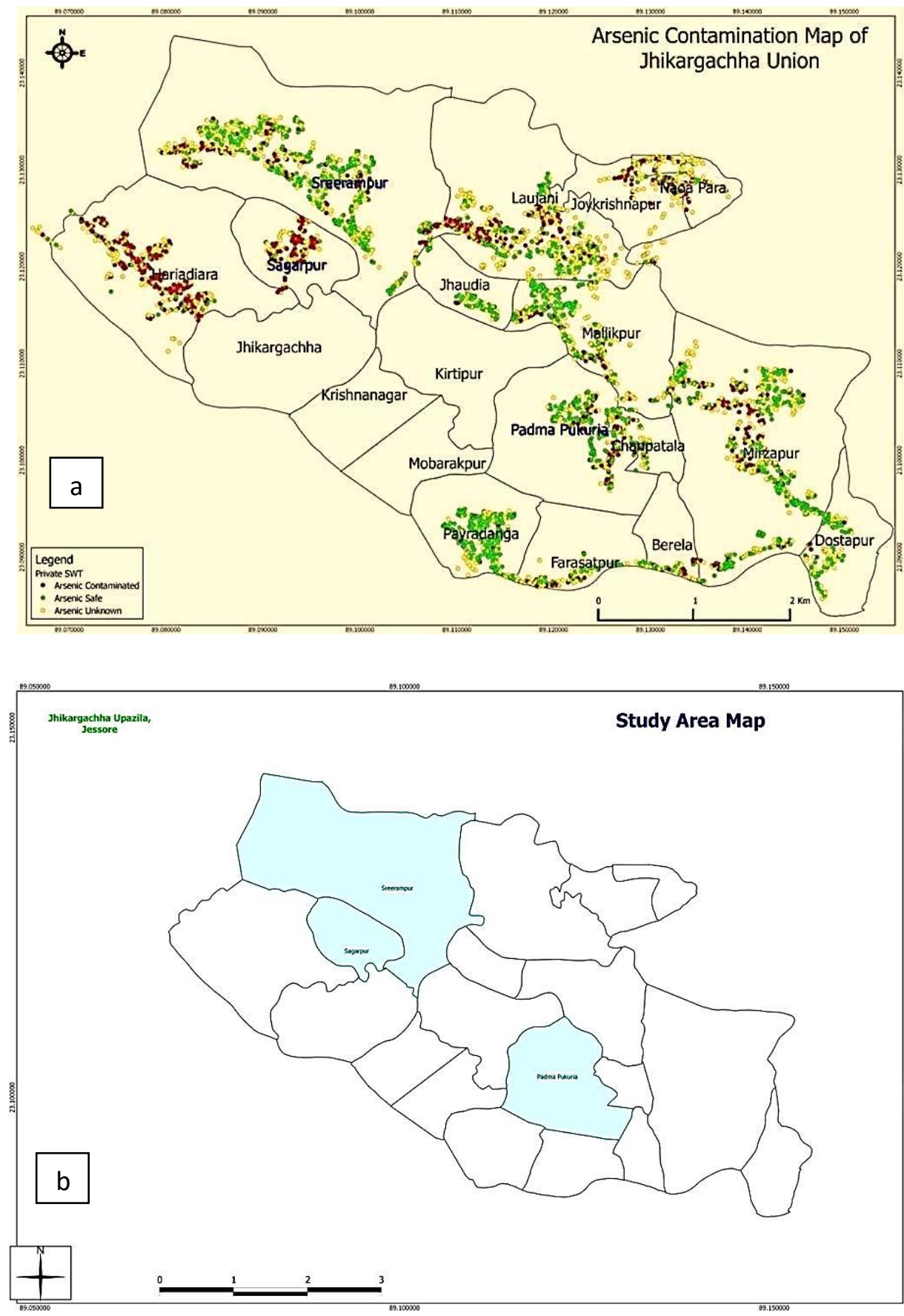

Figure 01 (a, b). Arsenic contamination map of Jhikargachha upazila (a) and study area (b). 
J. Sci. Technol. Environ. Inform. 04(01): 260-269 | Khan et al. (2016)

EISSN: 2409-7632, www.journalbinet.com

DOI: $10.18801 /$ jstei.040116.29

\section{Results and Discussion}

Education: Study showed that 54\% people were literate and 46\% people were illiterate. Figure 02 showed that graduate and higher secondary school (HSC) passed people were almost similar at Padmapukur and Srirampur villages, but Sagarpur village graduate and HSC passed people were lower than other two village. At three village, primary school (PSC) and secondary school (SSC) passed people were higher than the graduate and HSC level. SSC passed people were higher than PSC, HSC and graduate level education people.

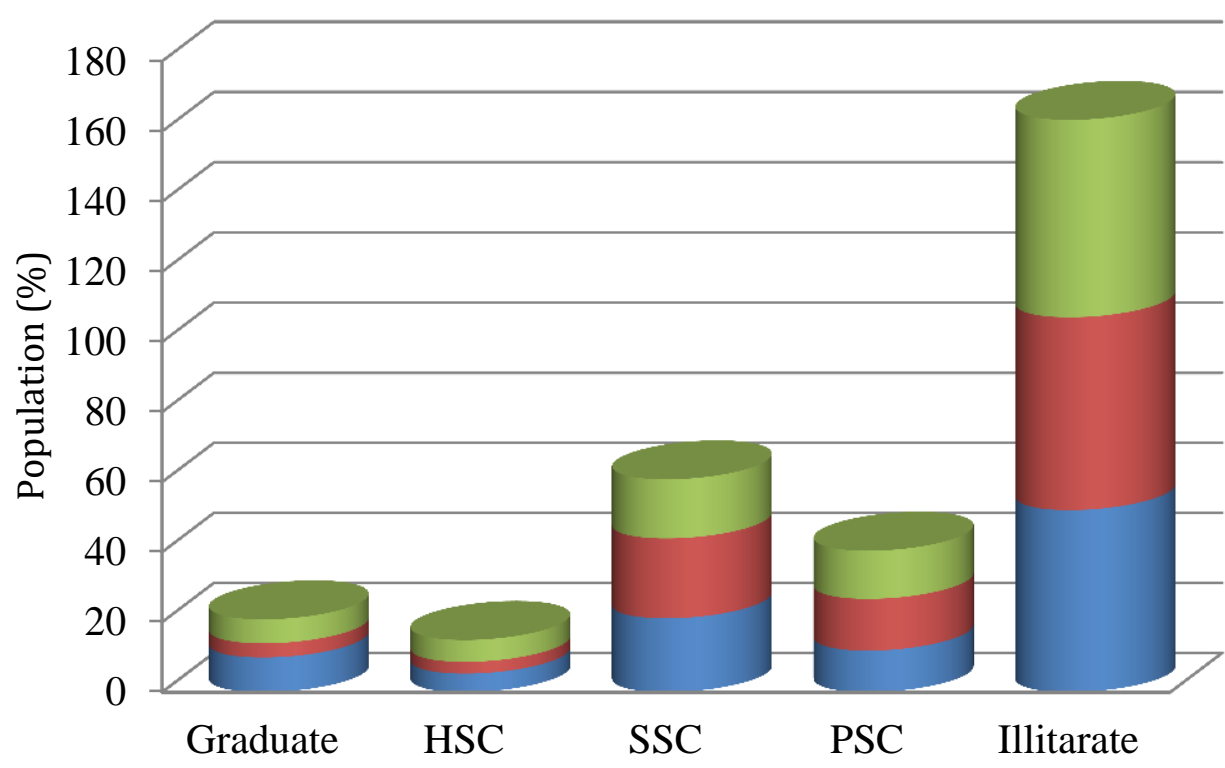

Education level.

Figure 02. Educational status.

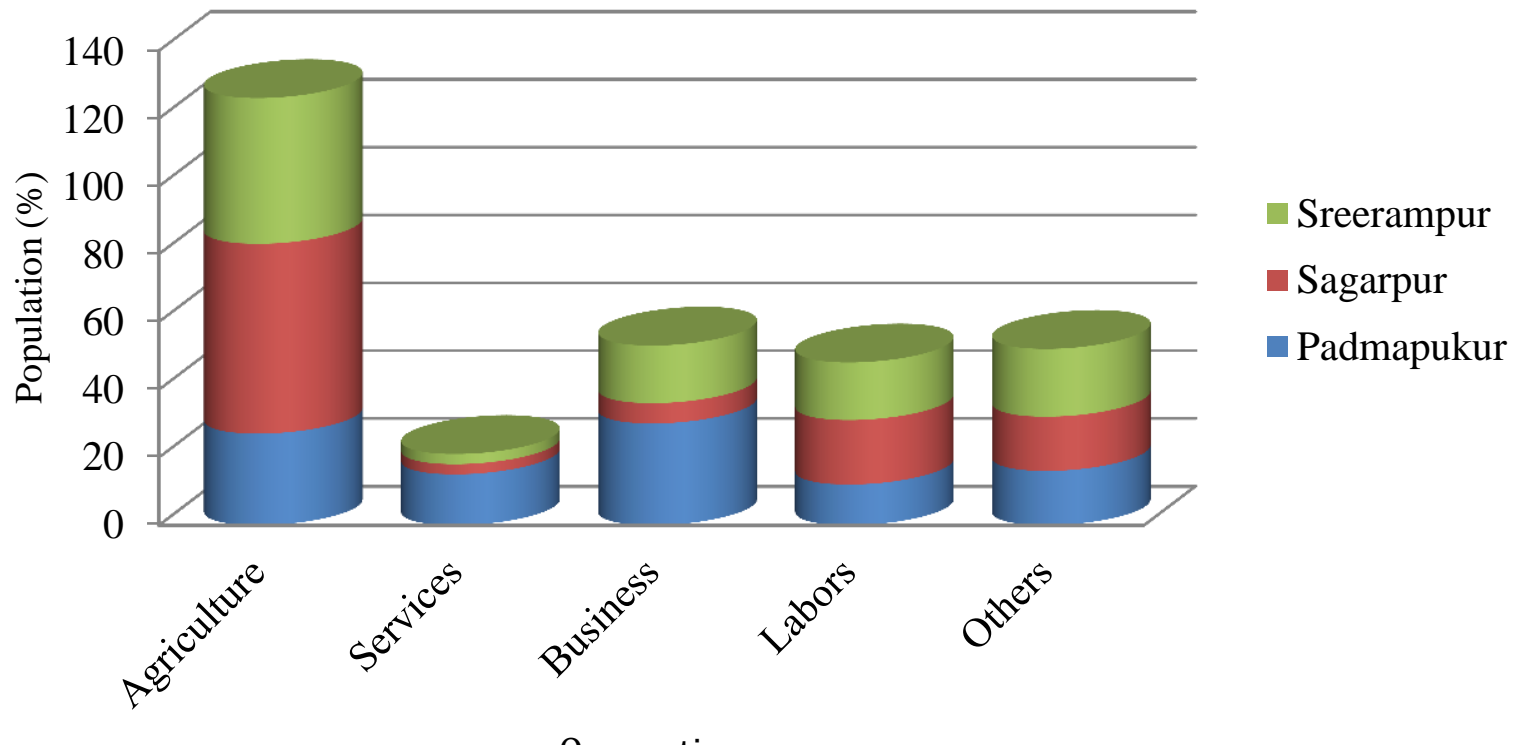

Figure 03. Occupational status.

Occupation: $42 \%, 7 \%, 18 \%, 16 \%$ and $17 \%$ people occupations were found agriculture, service, business, labour and others activities respectively. Figure 03 showed that maximum people 
occupation was found agriculture at three village but at Sagarpur village maximum (56\%)people occupation was agriculture. It showed that $30 \%$ people occupation was business at Padmapukur village which were higher than the others two villages. At Padmapukur village 15\% people occupation was service which was higher than others two villages.

Knowledge on arsenic and health hazards: Arsenic in drinking water is toxic for human health and it causes arsenicosis disease. Safe water is the first medicine for arsenicosis patients. 33\% tubewells were arsenic contaminated and34 arsenicosis patients were suspected due to arsenic contaminated water for drinking and cooking (NAMIC Data, 2004; JICA and AAN Report, 2015a; JICA and AAN Report, 2015b). 41\% peoples were aware of arsenic in ground water and $37 \%$ people were aware of arsenic health effects (arsenicosis). Figure $04 \&$ Figure 05 showed that knowledge on arsenic and its health effects. At Padmapukur village, 61\% people were known about arsenic toxicity but Sagrpur and Srirampur villages $25 \%$ \& $37 \%$ people were known about arsenic toxicity. On the other hand, Sagarpur village $100 \%$ people were unknown about arsenicosis disease. At Padmapukur village, 27\% people were known about arsenicosis but Srirampur village $83 \%$ people were known about arsenicosis. Results showed that many people were motivated on arsenic and its health effects through awareness by previously implemented various arsenic mitigation projects.

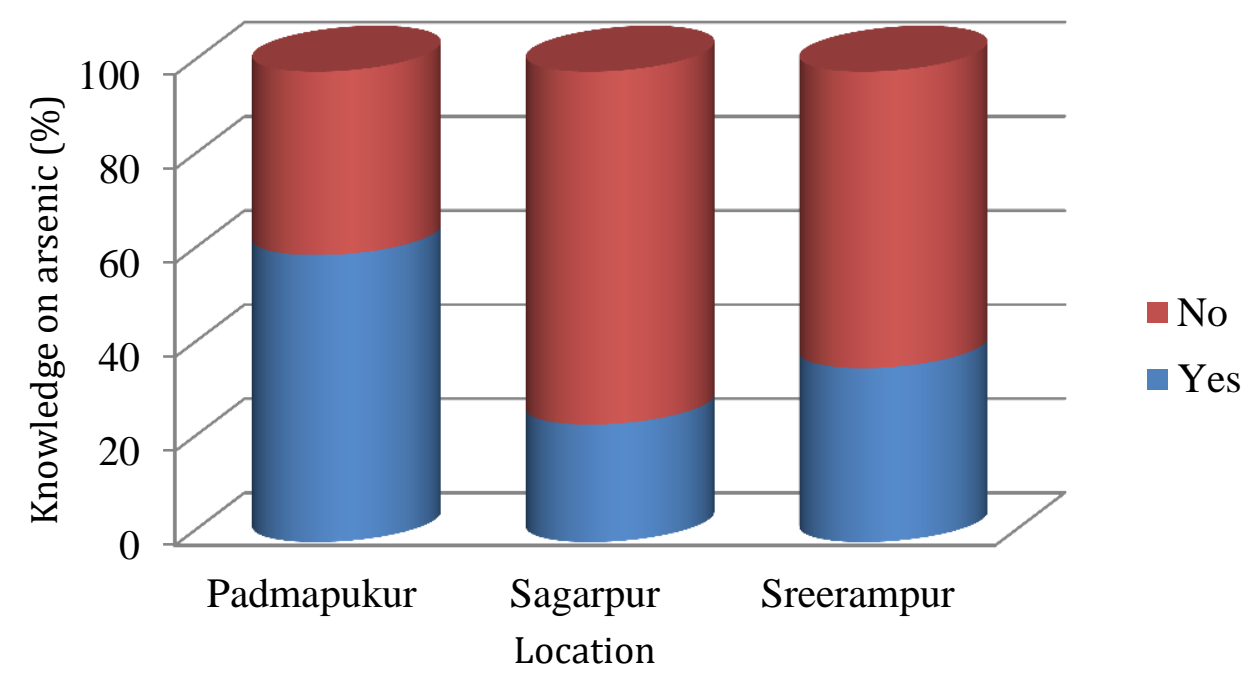

Figure 04. Knowledge on arsenic.

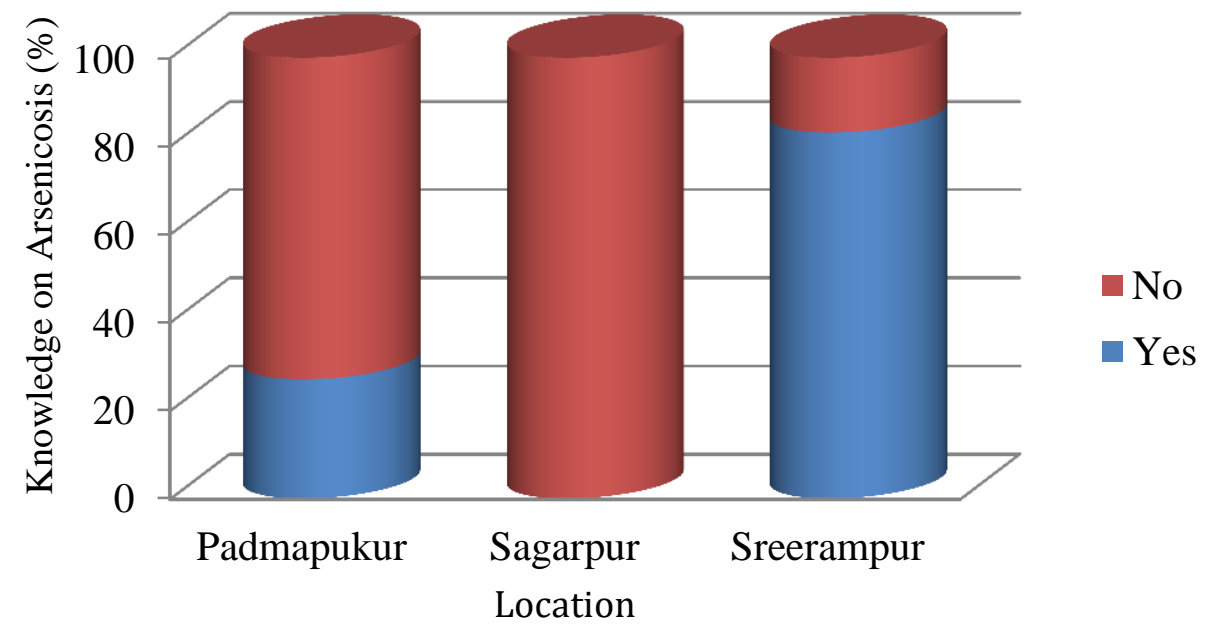

Figure 05. Knowledge on arsenicosis. 


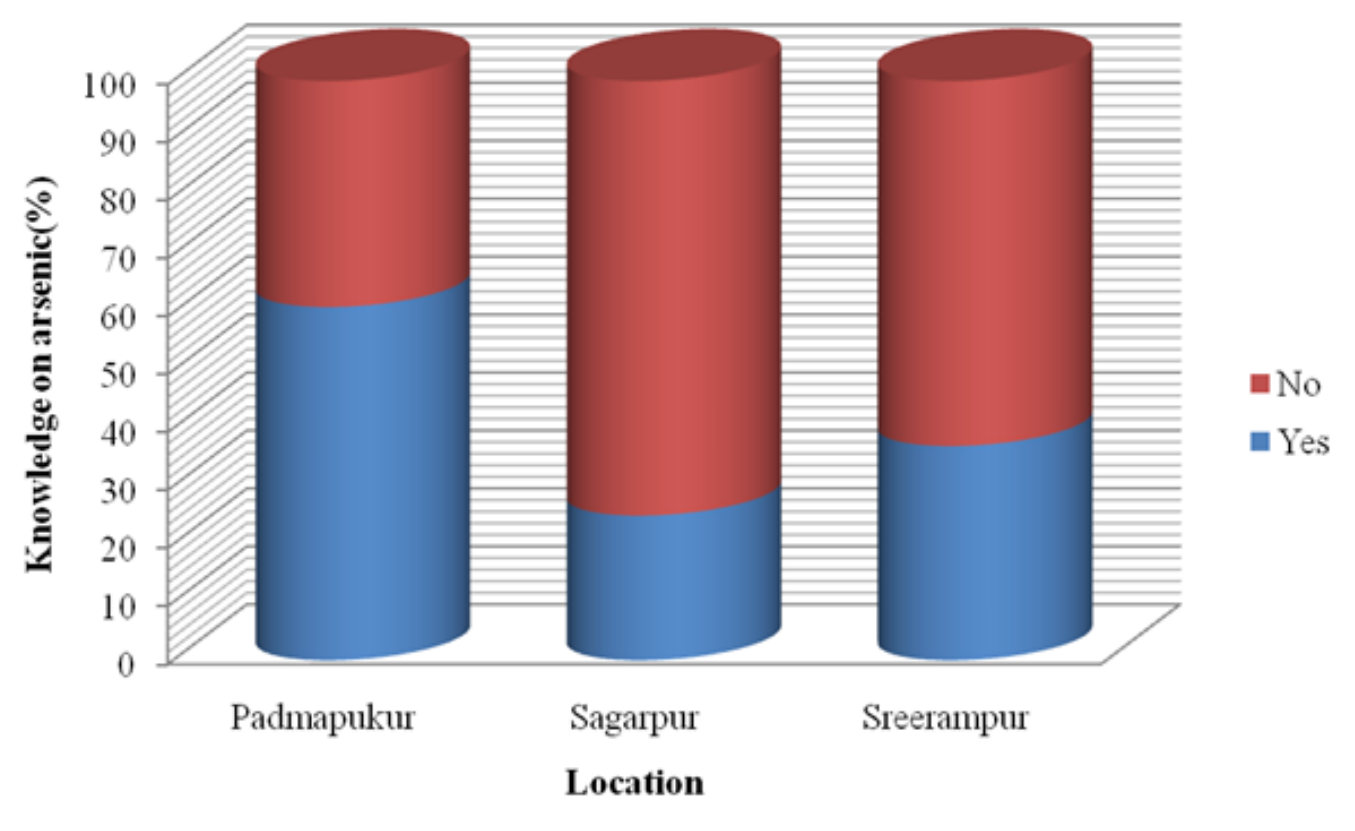

Figure 06. Drinking water safety status.

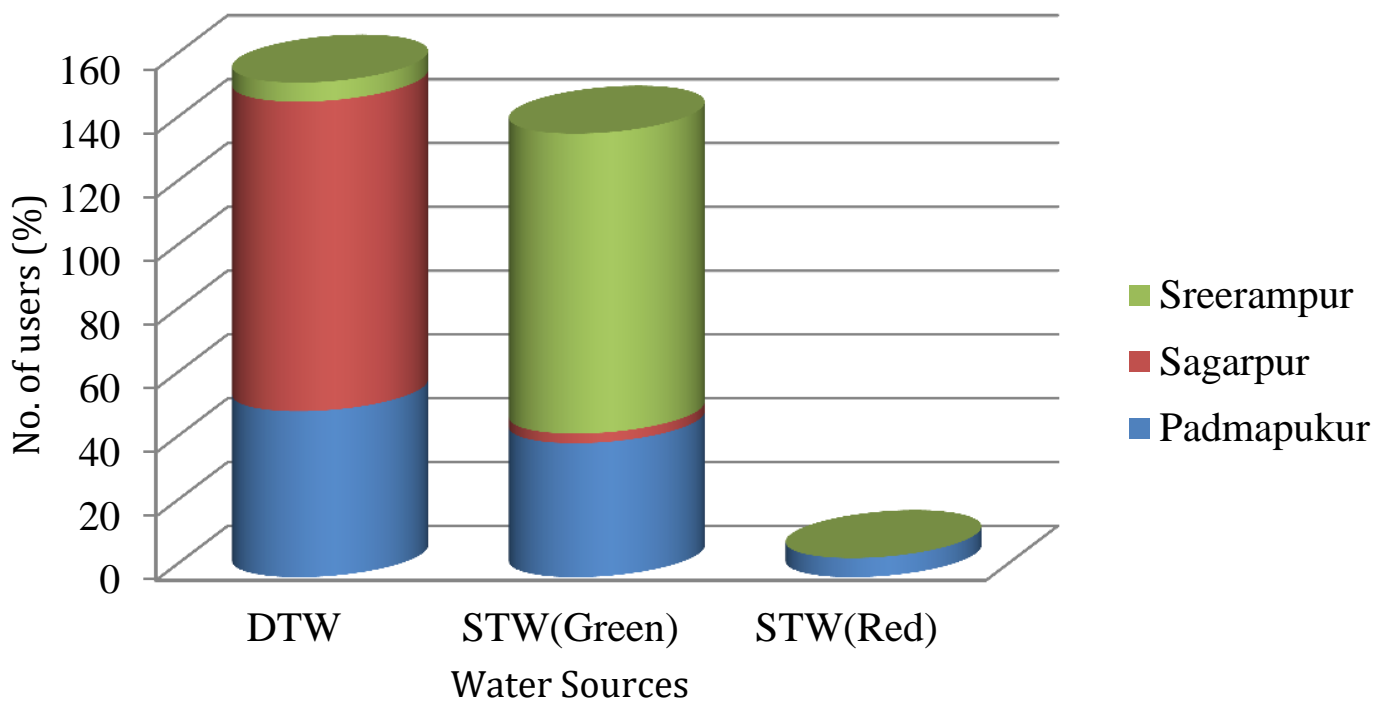

Figure 07. Safe water sources.

Drinking water arsenic contamination status: Rural area people were familiar with ground water for drinking and cooking; because they were aware that ground water was safe from microbiological and toxic metal contamination. But with time ground water became unsafe for human health due to arsenic contamination (NAMIC Data, 2004; JICA and AAN Report, 2015a; JICA and AAN Report, 2015b). 51\% shallow tubewells were safe from arsenic and 23\% tube well water was not safe from arsenic but $26 \%$ tube wells were not tested in this study area. Figure 06 showed that at Srirampur, Padmapukur and Sagarpur village 83\%, 58\% and 12\% shallow tubewells were safe from arsenic respectively; $0 \%, 21 \%$ and $47 \%$ shallow tubewells were not safe from arsenic respectively but $17 \%$, $21 \%$ and $41 \%$ shallow tubewells were not tested. At Srirampur village, shallow tubewells were safe $(<0.05 \mathrm{mg} / \mathrm{L})$ from arsenic and others two villages arsenic contaminated tubewells were higher than Srirampur village. At Sagarpur village, there was no arsenic safe shallow tube well and water safety level was very low for high arsenic contamination. 
Access of arsenic safe water: Arsenic contamination in ground water created serious health threats for 7644 peoples who are living at Sagarpur, Srirampur and Padmapukur village (NAMIC Data, 2004; JICA and AAN Report, 2015a; JICA and AAN Report, 2015b). According to arsenic contamination in shallow tubewells 23 safe water supply systems were installed in these study area (JICA and UNICEF Report, 2005; APSU Report, 2006; JICA and AAN Report, 2015a; JICA and AAN Report, 2015b). Community based arsenic safe water supply system was not familiar for rural area people, because at rural area people were habituated to use household based shallow tube wells water form their own source from the past years. It was a challenge to use arsenic safe water from the community based safe water sources by changing their previous practices. At the three villages, $52 \%$ people were collected arsenic safe water from deep tubewells and $46 \%$ people were collected arsenic safe water from green painted (arsenic safe) shallow tubewells which tubewells arsenic concentration was below $0.05 \mathrm{mg} / \mathrm{L}$. But only $2 \%$ people were still using arsenic contaminated tube wells water, whose tubewells arsenic concentration was exceed than Bangladesh drinking water standard $(>0.05 \mathrm{mg} / \mathrm{L})$. At Sagarpur, Padmapukur and Srirampur village, 97\%, 52\% and 6\% people were using arsenic safe water from deep tube wells and 3\%, 42\% and 94\% peoples were using arsenic safe water from green painted shallow tubewells respectively (Figure 07). On the other hand, at Padmapukur village 6\% people were using arsenic contaminated tubewells water for drinking and cooking. Srirampur village people were using their own green painted (arsenic safe) shallow tubewells for drinking and cooking due to low arsenic contamination in ground water. At Sagarpur village, people were highly accessed arsenic safe water due to high arsenic contamination in shallow tubewells and motivation on arsenic health threats. At Padmapukur village, people were using arsenic safe water from deep tube wells and arsenic safe shallow tubewells. At three villages, very few people were using red painted arsenic contaminated tube wells water. This study results showed that peoples were aware about arsenic and changing their habits to use arsenic safe water from green painted shallow tubewells and arsenic safe deep tubewells. Arsenic mitigation projects were succeeded for accessing arsenic safe water for this study area people.

Difficulties in safe water supply system sustainability: Safe water supply systems sustainability and its water safety depend on regular maintenance, water quality monitoring and community participation (JICA and UNICEF Report, 2005; APSU Report, 2006; JICA and AAN Report, 2015a; JICA and AAN Report, 2015b). Community people motivation and their participation is the most important for continuing access of safe water and its sustainability. As project activities was completed, afterwards safe water supply system faced difficulties due to community users participation, maintenance and water quality monitoring problems (JICA and UNICEF Report, 2005; APSU Report, 2006; JICA and AAN Report, 2015a; JICA and AAN Report, 2015b). 70\% people were interested to pay their users share for safe water device installation but 35\% people were interested to pay maintenance cost share. Padmapukur and Sagarpur village $72 \%$ and $100 \%$ people were very much aware to pay the user share for safe water supply system installation because of highly arsenic contamination in tubewells water and lack of safe water source availability. On the other hand, at Srirampur village, $37 \%$ people were interested to pay user share for safe water supply system installation, because they have available safe water sources (green painted STW) in near their house. After installation of safe water device regular maintenance and water quality monitoring is the most important for water safety. Financial availability is essential for paying the installation cost, maintenance cost and water quality testing cost. This maintenance cost should be paid by user families, which in turn will be expense for safe water device maintenance and water quality monitoring cost. $35 \%$ people were interested to pay monthly maintenance cost, but $65 \%$ people were not interested to pay monthly maintenance cost due to lack of motivation on community participation. Figure 08 and Figure 09 showed that at Padmapukur, Sagarpur and Srirampur village, 33\%, 25\% and $46 \%$ people were interested to pay monthly user fee for safe water device maintenance and water quality monitoring cost. On the other hand, Padmapukur, Sagarpur and Srirampur village, 67\%, 75\% and $54 \%$ people were not interested to pay monthly user fee for safe water systems maintenance cost. Community participation was not enough for safe water system sustainability due to user motivational problems of safe water systems installation and maintenance cost sharing practice. More 
awareness and motivation related activities are necessary for increasing the community participation and making a good practice for paying the regular maintenance cost.

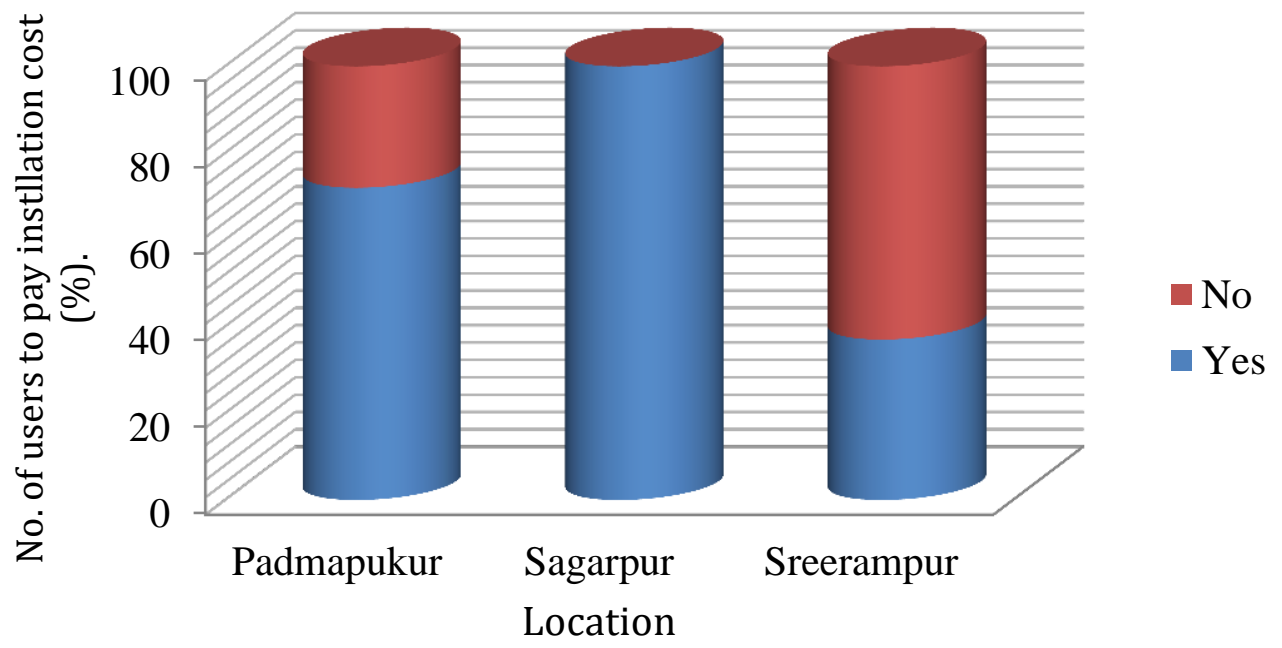

Figure 08. User share payment for safe water supply system installation.

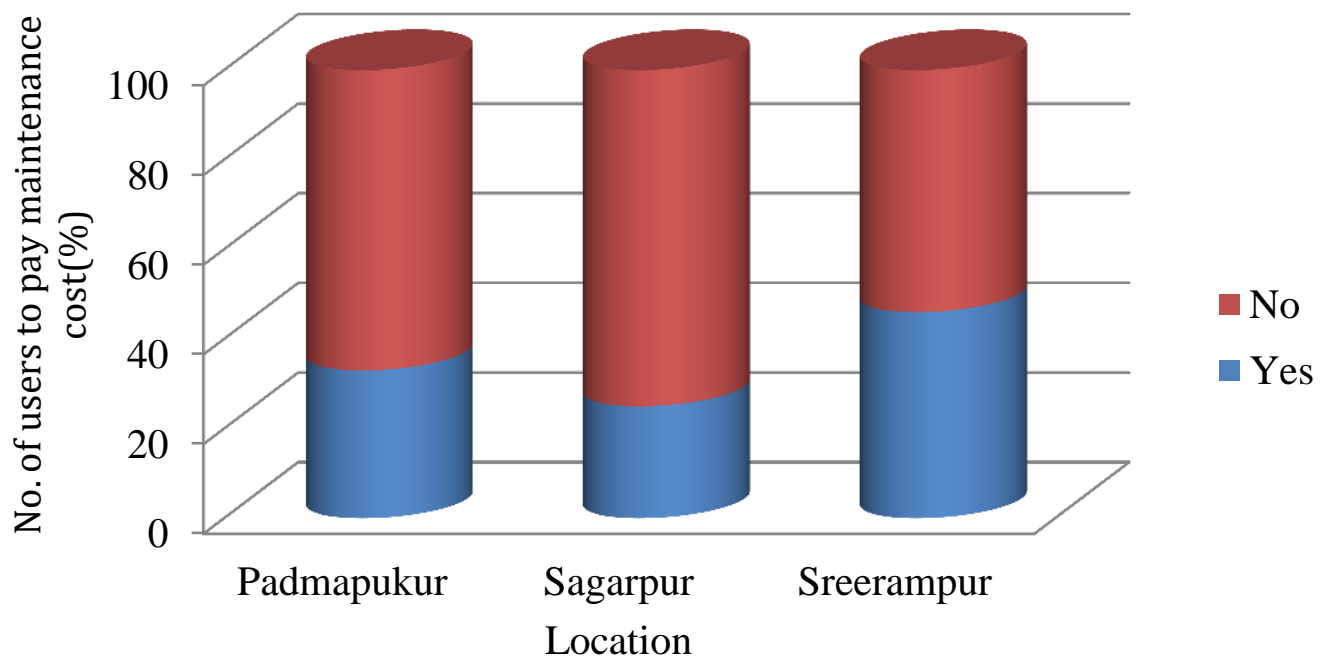

Figure 09. User share payment for safe water supply system maintenance cost.

\section{Conclusion}

During 1993-2015, many organizations conducted arsenic mitigation and water supply projects in these study areas for changing the drinking water status and risk assessment of arsenic contamination in ground water. People from all three villages were highly motivated by awareness related activities. People were aware about to check their tubewell water arsenic safety level and how to get the safe water from arsenic safe deep tube wells or green painted shallow tube well. But user participation practices were not established for safe water supply system development, regular maintenance and water quality monitoring. People were not interested to pay user share for maintenance of safe water supply system. In case of Sagarpur village, user families were motivated and benefited from various arsenic mitigation projects. Sagarpur and Srirampur village $97 \%$ and $94 \%$ people were access to arsenic safe water for drinking and cooking purpose. The ground water arsenic contamination has become a serious public health problem in Bangladesh. Proper management of arsenic pollution is a challenge for Bangladesh. To combat this gigantic problem, appropriate planning and leadership from 
the government, non-government organization and active participation of the scientific community, user communities are essential.

\section{Acknowledgement}

Authors gratefully acknowledge to Villagers, Jhikargachha sadar union parishad, Department of Chemical Engineering (Jessore university of Science and Technology), JICA-AAN MBSWSS Project \& Asia Arsenic Network for helping the research study and sharing their valuable information and materials for completing this work.

\section{References}

[1]. Ali, M. A., Badruzzaman, A. B. M., Jalil, M. A. \& Hossain, M. D. (2001). Development of low-cost technologies for removal of arsenic from tubewell water, Draft final report presented to the United Nations University, Tokyo, Japan.

[2]. APSU (2006). A sustainability of arsenic mitigation: A survey of the functional status of water supplies. Arsenic Policy Support Unit, Dhaka, Bangladesh.

[3]. Bhattacharya, P., Frisbe, S. H., Smith, E., Naidu, R., Jacks, G. \& Sarkar, B. (2002). Arsenic in the Environment: A global perspective. In: B. Sarkar (Ed). Hand Book of Heavy Metals in the Environment, Marcell Deeker Inc., New York. pp. 147-215.

http://dx.doi.org/10.1201/9780203909300.ch6

[4]. British Geological Survey (1999). Ground water studies for arsenic contamination in Bangladesh. Phase1, Main report.

[5]. Caroli, F. L. A Tore, Petrucci, F. \& Violante, N. (1996). Element Speciation in Bio-inorganic chemistry (Edited by Sergio Caroli). Chemical Analysis Series, 135, 445-463.

[6]. FAO, UNICEF, WHO \& WSP (2010). Towards an Arsenic Safe Environment in Bangladesh. A publication of World Water Day, 22 March, 2010, Dhaka, Bangladesh.

[7]. Hossain (2001). Approaches for removal of arsenic from drinking water. A publication of BUET-UNU international workshop on technologies for arsenic removal from drinking water, Dhaka, Bangladesh, ISBN 984-31-1305-6. pp. 69-70.

[8]. JICA \& AAN (2015a). Situation Analysis of Safe Water Supply by using GIS map in Jhikargachhha Upazila, Jessore. A Summary Report on MBSWSS Project, Jessore, Bangladesh.

[9]. JICA \& AAN (2015b). Model Building for Safe Water Supply Service by Local Government Institution (Union Parishad). A Final Report on MBSWSS Project report, Jessore, Bangladesh.

[10]. JICA \& UNICEF (2005). Practical Approach for Efficient Safe Water Option. JICA and UNICEF, Dhaka, Bangladesh.

[11]. NAMIC (2004). Upazila-wise summary of screening results. BAMSWP project, Dhaka, Bangladesh.

[12]. Saha, J. C. (1999). Removal of arsenic from water environment by new adsorbent, PhD. Thesis.

[13]. Smith, Lingas, A. H. E. O. (2000). Contamination of drinking -water by arsenic in Bangladesh: a public health emergency. Bulletin of World health Organization, 78(9), 1093-1103.

[14]. SOS Survey report (2006). www.sos-arsenic.net.

[15]. TOROKU (2005). Bridging Arsenic-affected Asia. Kyushu Rokin Bank, NPO AID Scheme publication, Miyazaki, Japan. p. 9.

[16]. WHO and UNICEF (2000). Global water supply and sanitation assessment, 2000 report. World Health Organization (WHO) and United Nations Children's Fund (UNICEF), Geneva and New York. 
J. Sci. Technol. Environ. Inform. 04(01): 260-269 | Khan et al. (2016)

EISSN: 2409-7632, www.journalbinet.com

DOI: $10.18801 /$ jstei.040116.29

[17]. WHO and UNICEF (2004). Meeting the MDG drinking water and sanitation target: a midterm assessment of progress. World Health Organization and United Nations Children's Fund, Geneva and New York.

\section{How to cite this article?}

\section{APA (American Psychological Association)}

Khan, M. A. S., Waliullah, M., Hossain, M., Mandal, B. H., Habiba, U. \& Siddique, M. N. A. (2016). Safe water access, motivation and community participation at arsenic affected rural areas of Jessore, Bangladesh: insights and realism. Journal of Science, Technology and Environment Informatics, 04(01), 260-269.

\section{MLA (Modern Language Association)}

Khan, M. A. S., Waliullah, M., Hossain, M., Mandal, B. H., Habiba, U. \& Siddique, M. N. A. "Safe water access, motivation and community participation at arsenic affected rural areas of Jessore, Bangladesh: insights and realism." Journal of Science, Technology and Environment Informatics, 04.01 (2016): 260-269.

\section{Chicago/Turabian}

Khan, M. A. S., Waliullah, M., Hossain, M., Mandal, B. H., Habiba, U. \& Siddique, M. N. A. Safe water access, motivation and community participation at arsenic affected rural areas of Jessore, Bangladesh: insights and realism. Journal of Science, Technology and Environment Informatics, 04, no. 01 (2016): 260-269. 